\title{
ABCB1 AND SLCO1B1 GENE POLYMORPHISMS PREDICT METHOTREXATE-RESISTANCE IN LOW-RISK GESTATIONAL TROPHOBLASTIC NEOPLASIA
}

Manasawee Srisuttayasathien', Nutthada Areepium², Ruangsak Lertkhachonsuk ${ }^{1}$

1 Division of Gynecologic Oncology, Department of Obstetrics and Gynecology, Faculty of Medicine, Chulalongkorn, University and King Chulalongkorn Memorial Hospital, Bangkok, Thailand

${ }^{2}$ Department of Pharmacy Practice, Faculty of Pharmaceutical Sciences, Chulalongkorn University, Bangkok, Thailand

\section{INTRODUCTION}

Methotrexate, as a single agent, has long been used successfully and is preferred worldwide for the treatment of low-risk gestational trophoblastic neoplasia. However, up to $26 \%$ of patients develop resistance and require changes to second-line chemotherapy. In the search for personalised treatment approaches, a link has been found between the pharmacogenomics of methotrexate response in various diseases

\section{OBJECTIVES}

To explore the effects of $A B C B 1$ and SLCO1B1 gene polymorphisms and the methotrexate treatment response in patients with low-risk gestational trophoblastic neoplasia. Secondary objectives were to investigate the association of single nucleotide polymorphism (SNP) genotypes with toxicity profiles, and to evaluate other factors associated with the response.

\section{METHODS}

Records of all patients with low-risk gestational trophoblastic neoplasia were reviewed and patients who received methotrexate as a firstline single agent were invited to participate in the study.
DNA was extracted from peripheral blood samples from 18 patients and assessed for ABCB1 $(3435 C>T)$ and SLCO1B1 (521T>C).

\section{RESULTS}

For the ABCB1 polymorphism, CT was the most common genotype (61.1\%), followed by CC (27.8 \%) and TT (11.1\%). Patients with TT had a 1.6-fold higher risk of methotrexate-resistance when compared to the wild-type and heterozygous alleles. The risk of methotrexaterelated toxicity was 2.67 -fold higher in CT/CC patients who showed a better response to methotrexate. SLCO1B1 gene was not associated with treatment outcomes.

\begin{tabular}{|c|c|c|c|c|}
\hline \multirow{2}{*}{ ABCB1 } & \multicolumn{2}{|c|}{$\begin{array}{l}\text { Methotrexate } \\
\text { Response }\end{array}$} & \multirow[t]{2}{*}{$\begin{array}{l}\text { Odds } \\
\text { ratio }\end{array}$} & \multirow[t]{2}{*}{$95 \% \mathrm{Cl}$} \\
\hline & Resistant & Sensitive & & \\
\hline $\begin{array}{l}\text { TT } \\
\mathrm{CT} / \mathrm{CC}\end{array}$ & $\begin{array}{c}2 \\
10\end{array}$ & $\begin{array}{l}0 \\
6\end{array}$ & 1.6 & $\begin{array}{l}1.095- \\
2.339\end{array}$ \\
\hline \multirow[b]{2}{*}{ ABCB1 } & \multicolumn{2}{|c|}{ Adverse Effects } & \multirow{2}{*}{$\begin{array}{l}\text { Odds } \\
\text { ratio }\end{array}$} & \multirow[t]{2}{*}{$95 \% \mathrm{Cl}$} \\
\hline & Yes & No & & \\
\hline $\begin{array}{l}\text { TT } \\
\text { CT/CC }\end{array}$ & $\begin{array}{c}0 \\
10\end{array}$ & $\begin{array}{l}2 \\
6\end{array}$ & 2.67 & $\begin{array}{l}1.417- \\
5.020\end{array}$ \\
\hline & CON & USION & & \\
\hline
\end{tabular}

$A B C B 1$ polymorphism might be useful as a biomarker for predicting the response to methotrexate in patients with low-risk gestational trophoblastic neoplasia. 